\title{
A Comment on Professor Waldron
}

\section{Hanna Pitkin $\dagger$}

Jeremy Waldron juxtaposes two conflictimg propositions he says are exemplified in the controversy over Bowers v. Hardwick:" that "a community is entitled to uphold and enforce its own distimctive mores, norms, and standards," and that the "moral consensus" of a coinmunity is valid only if "it measures up to abstract principles drawn out of the very idea of individual fulfillment and the respect that people owe to one another." 3 The former he calls "communitarian," the latter "liberál."4

It seeins evident to ine that (almost) all of us are deeply committed to both of Waldron's propositions as part of our traditional heritage. Think, for example, of our Declaration of Independence, invoking as obvious the right of any "people" to "dissolve the political bands which have connected it with another," yet proceeding instantly to principled justification out of "a decent respect to the opimions of mankind." Or reach even further back, to the Puritans of New or old England: Who could have been inore committed to the shining "city on the hill" in which eacli is his brother's keeper, yet who could have been more sensitive to the ultimately individual responsibility of each conscience before God?

Indeed, Waldron's two propositions are interdependent. Not only is the principled, abstract assessinent of norms, as he shows, one of the distinctive traditional norms of our community, but the converse connection also holds: It is partly because people owe one another respect as inoral agents that they are entitled jointly to govern theinselves and set norms for their commumity.

Still, there inust be a conflict in here somewhere. There are decisions to be made, positions to be taken. Was Bowers v. Hardwick a right decision or not? Either of Waldron's propositions, however, will support either conclusion. Consider:

(1) A community is entitled to impose norms on itself, for instance against homosexual sodomy, so Bowers was a right decision.

$\dagger$ Professor of Political Science, University of California, Berkeley. B.A. 1953, University of California, Los Angeles; M.A. 1954, University of California, Los Angeles; Ph.D. 1961, University of California, Berkeley.

1. 478 U.S. 186 (1986).

2. Waldron, Particular Values and Critical Morality, 77 CALIF. L. Rev. 561, 561 (1989).

3. Id. at 562 .

4. Id. at 561-62. 
2) A community is entitled to impose norms on itself, such as those of limited government, individual rights, personal fulfillment, so Bowers was a wrong decision.

3) Moral validity derives only from abstract principles based on respect for persons, hence on the right of each to define his or her own sexuality; so Bowers was wrong.

4) Moral validity derives only from abstract principles based on respect for persons, hence on respect for their right to set norms for their community such as those against homosexual sodomy, so Bowers was right.

Are general propositions of no use, then, in such decisions, or have we started from the wrong propositions, or what?

Waldron offers two useful suggestions here, but I shall argue, he neglects a third, linking consideration and thereby partly undermines his own position. His first suggestion is the distinction between the "insider's" and the "outsider's" stance, between actually applying, justifying, or revising our norms and merely describing them or explaining their social function or historical origins, as a social scientist might. ${ }^{5}$ In these terms, my point, above, is that our tradition includes norms requiring of us both that we take an "outsider's" stance toward our norms where they conflict with those of others, rather than privilege our own (don't treat yourself as an exception, don't be ethnocentric or prejudiced, be tolerant, be fair, be objective in judgment, and so on), and that we take an "insider's" stance rather than dissolve in bland relativism (stand up for what is right, accept responsibility, call a spade a spade, help those in need, and so on). And the question is, how do we know when to apply which of these two requirements?

Toward answering that question, Waldron offers another distinction, between those norms we regard as relatively trivial-merely "the way we happen to do things around here"-and those we take really seriously as fundamental commitments, perhaps even constitutive of who we are. ${ }^{6}$ Toward the former we can easily assume the "outsider's" stance, and morally must do so when they come into conflict with the norms of another community, especially when that community holds those values to be deep commitments. If we don't much care and they do, it's only fair that we give way. Toward our own seriously held norms, however, we may not morally take an "outsider's" stance, or we betray what is right and support what we know is wrong. Thus the way to tell when to take an "outsider's" and when an "insider's" stance would be by the intensity of commitment or feeling about the norms involved (ours and theirs).

Now, this might be an accurate account of what we in fact tend to

5. Id. at $574-75,578-79$.

6. Id. at 576-77. 
do, an "outsider's" description of our behavior: Where we don't much care, we'll compromise; where emotions run high, we won't. But as a justification, as an account of our moral obligations, it won't do at all.

We do-and morally must-care deeply about (at least some) moral issues, but we also care deeply about some aesthetic, political, religious, and scientific issues, as well as practical ones and personal preferences. I may, for example, find Eskimo food repulsive and their cosmetic practices disgustimg to the point of nausea. Given human weakness, I might even for that reason condemn those practices as barbaric, immoral, and inhuman. But that would constitute a flagrant abuse, not a paradigmatic example, of moral judgment.

Most liuman practices are per se neither moral nor immoral, and their moral status is not determined by how intensely we cling to or reject them. The inorahty of a particular judgment may depend less on the practice being judged (hoinosexuality is a moral issue; surfing is not) than on qualities of the judgment. Whether the widespread traditional condemnation of loinosexual sodomy is a moral judgment ratler than, say, an aesthetic one or a mere habitual, groundless prejudice like my nausea at certain Eskimo practices, will depend on what, in particular, counts as a moral judgment, issue, practice, concern, or reason.

This is the point, it seens to me, that Waldron neglects. He simply does not ask what counts as morality, and lie writes in ways that obscure rather than illuininate the concept. He refers, for exainple, to "the extent [to which] there is a moral rule against homosexual intercourse in parts of the United States." I I do not doubt that homosexuality is widely condeinned (and widely practiced) in (almost) all parts of the United States. Does that show the existence of a "moral rule" against it? Are there rules in morality? Could one perhaps look them up in soine moral Hoyle? It seems to me utterly wrong to think of morality as a system of rules classifying kinds of action into those forbidden, those permitted, and those required, so that there will appear to be in America "literally thousands of inoralities jostling and competing with one another in the inarketplace." 8

Even inore misleading liere than the notion that morality is a system of rules and hence that a difference in rules produces a difference in morality is the innplicit assunption that all norms, standards, conventions, and regularities in human conduct are noral ones. This is not the place to analyze the concept of morality at any length, nor do I feel coinpetent to do so. One criterion of a moral clain or judgment miglit be whether it is conceived in terms of what will benefit the person

7. Id. at 574 .

8. Id. at 583 . 
addressed. Another might be whether it regards people as members of the Kingdom of Ends rather than mere means to the speaker's ends. Another might be whether the claim or judgment is principled, generalizable, capable of being a maxim for the conduct of all others similarly situated. My point is only that the matter needs to be addressed.

The failure to address it has at least three unfortunate consequences. First, as may already be evident, I am here juxtaposing an "insider's" perspective on morality itself to the implicit and unexamined "outsider's" stance imposed by Waldron's essay. We need to leave ourselves room for thought and choice here, because our moral tradition requires both stances of us; it requires us at times to acknowledge that others may have moral views profoundly different from our own, and at other times to reject an action or code of conduct as immoral or even inimical to the very nature or morality. The way Waldron treats morality in this essay is bound to feed rather than combat that relativistic caricature of tolerance, that tolerance he rightly condemns in those he calls communitarians (though some might associate it equally with liberals).

Second, the concept of morality should prove helpful for thinking about when our tradition requires of us an "outsider's" stance and humility, and when it requires an "insider's" stance and commitmentat any rate it should prove more helpful than the notion of intensity of feeling. But it cannot do so until its meaning is taken seriously.

Third, lumping morality together with every other standard, norm, or convention governing conduct, or with every one about which we feel deeply, is bound to reinforce that Manichaean dichotomy so pervasive in our time between "facts" and "values," or between the "descriptive" and the "normative," in which morality (not to mention politics, aesthetics, and law) gets construed as mere "subjective" preference, like one's taste in ice cream. That, in turn, rules out the very possibility of rational justification or deliberation, that critical reflection on "what is really right and really wrong" for which Waldron rightly praises liberals (though some may think communitarians and radicals do it too, or even do it better). ${ }^{9}$

Clearly, these bad consequences are not part of Waldron's intention; some attention to the concept of morality should therefore strengthen what is in many other respects a brilliant and admirable essay.

9. Id. at 578 . 